\title{
Lecturers' Instructional Practice based on Students' Core Competencies Development: A Study Conducted at English Education Department
}

\author{
Hadiyanto $^{1}$, Syahrial ${ }^{1}$, Akhmad Habibi ${ }^{1}$, Nunung Fajaryani ${ }^{1}$, Masbirorotni ${ }^{1}$, Failasofah ${ }^{1}$, \\ ${ }^{1}$ Universitas Jambi, Jl. Lintas Jambi - Muara Bulian Km. 15, Mendalo Darat, Jambi Luar Kota, \\ Kota Jambi, Jambi 36122, Indonesia
}

\begin{abstract}
This study examined the development of English Education students' core competencies based on lecturers' intsructional practice report. The core competencies in this research include two domain: soft skills and hard skills. Soft skills and hard skills are categorized into sub-domain. Self evaluation questionnaire using likert scale 1 to 5 responses were distributed to 30 lecturers, and 23 returned. The interpretation of mean score was catagorized into five level; very low, low, medium, high and very high. The findings showed that lecturers rated their instructional practices in developing studens' soft skills, and hard skills, and in overall core competencies were at high level. In subskills of soft skills showed that instructional practices in term of communication skills, learning how to learn skills, problem solving skills and working with others were rated at high level, while IT skill and numeracy skills were practiced at medium level. It is assumed that the level of instructional practices of core competencies will impact on unsatisfied level of students' core competencies output. This study suggested that faculty and department should take a role in implementation of instructional practice based on students core competencies development.
\end{abstract}

Keywords: core competencies; soft skills; hard skills; instructional practice; higher education

\section{INTRODUCTION}

A number of studies related to students and graduate core competencies level have been done continuously until today following the challenges from years to year, such as (Hadiyanto, Mukminin, Failasofah. Arif, Fajaryani, and Habibi, 2017, British Council, 2016; Aclan, E. M, Noor Hashima \& Valdez, N. P. 2015; Laura, et al (2015), Su and Zang (2015), Hadiyanto and Suratno (2015), Hadiyanto \& Mohammed Sani (2013), Lowden et al. (2011), Jones (2009), Hogarth et al. (2007), the Business Council of Australia (BCA, 2006), Zalizan et al. (2006), Norzaini et al. (2005), Crebert et al. (2004), Bath et al. (2004), Pumphrey and Slater (2002), Curry et al. (2003), Borthwick and Wissler (2003), and others studies across countries that are different terminology used. The terminology of core competencies used such as $21^{\text {st }}$ century skills, transferable skill, key skills, soft skills, generic skills and others terms. The term 'core competencies' are used in Indonesian higher curriculum (Tim Kurikulum dan Pembelajaran Direktorat Pembelajaran dan Kemahasiswaan, 2014) and Indonesian 
Qualification Framework (Dikti, 2011). Both Indonesian Higher Education Curriculum (Tim Kurikulum dan Pembelajaran Direktorat Pembelajaran dan Kemahasiswaan, 2014) and Indonesian Qualification Framewok (Dikti, 2011) states that the students' must be provided with core competencies including soft skills and hard skills.

Most of the studies as mentioned above state that the development of core competencies is best facilitated by giving students practice and not by simply talking about or demonstrating what to do. The teaching approach is no longer monotonies on lecture, and slide presentation only where a lecturer standing in front of class exchanges slide by slide. The teaching and learning at university level now, is students centered where the students build their core competencies through various learning activities in the classroom.

The Education English graduates should not just be prepared for specific knowledge and technical skills of English such as grammar, reading, listening, speaking, writing, discourse analysis, teaching skills, e.tc, but also be prepared to enhance, accommodate, and apply their soft skills at work place. That is why the students' core competencies development must be embedded in instructional practices and be evaluated from time to time (British Council, 2016; Aclan, E. M, Noor Hashima \& Valdez, N. P. 2015; Marie and Donna, 2013; Bartel, 2011).

The implementation of instructional practice based on students' core competencies development had been stated as curriculum policy at national level and at university level. In University of Jambi, the implementation had been started since 2014 by referring to guidance of curriculum of DIKTI (Tim Kurikulum dan Pembelajaran Direktorat Pembelajaran dan Kemahasiswaan, 2014; English Education Program, Faculty of Teacher Training and Education, Universitas Jambi, 2015; Indonesian Qualification Framewok, 2011).

In relation with this study, though core competencies based learning had been stated in description and objective of curriculum of Education English (English Education Program, Faculty of Teacher Training and Education, Universitas Jambi, 2015), however there is no yet instrument developed to measured students core competencies development. And research upon instructional practices conducted dealing with students' core competencies development and the monitoring and evaluation of students' core competencies development had not been conducted. Therefore, this study aimed to examine, describe and report the development of English Education students' core competencies based on lecturers' instructional practice report. It was conducted at English Education Department in Universitas Jambi. The result had been classified and discussed according to a main construct, and then breakdown into sub-construct.

In addition, the result of the study will be contributed as reference to develop the model of students' core competencies development that is being funded by Indonesian Ministry of Research, Technology and Higher Education year 2016 to 2018. 


\section{LITERATURE REVIEW}

\section{Defining Art Competencies}

In this study, by refereeing to some previous resources such as Hadiyanto \& Suratno, 2015, Bialik, et., al. (2015), Hassan., et. al. (2013), Hadiyanto \& Mohammed Sani (2013), Hadiyanto.(2011), Hadiyanto, (2010), and Zalizan., et. al (2006) core competencies are reconceptualised and redefined as skills developed during teaching and learning process at university in order to provide students with competencies; Soft Skills and English Hard Skills. For obtaining the aim of the study, the writer formulated the conceptual framework as shown in Figure 1.

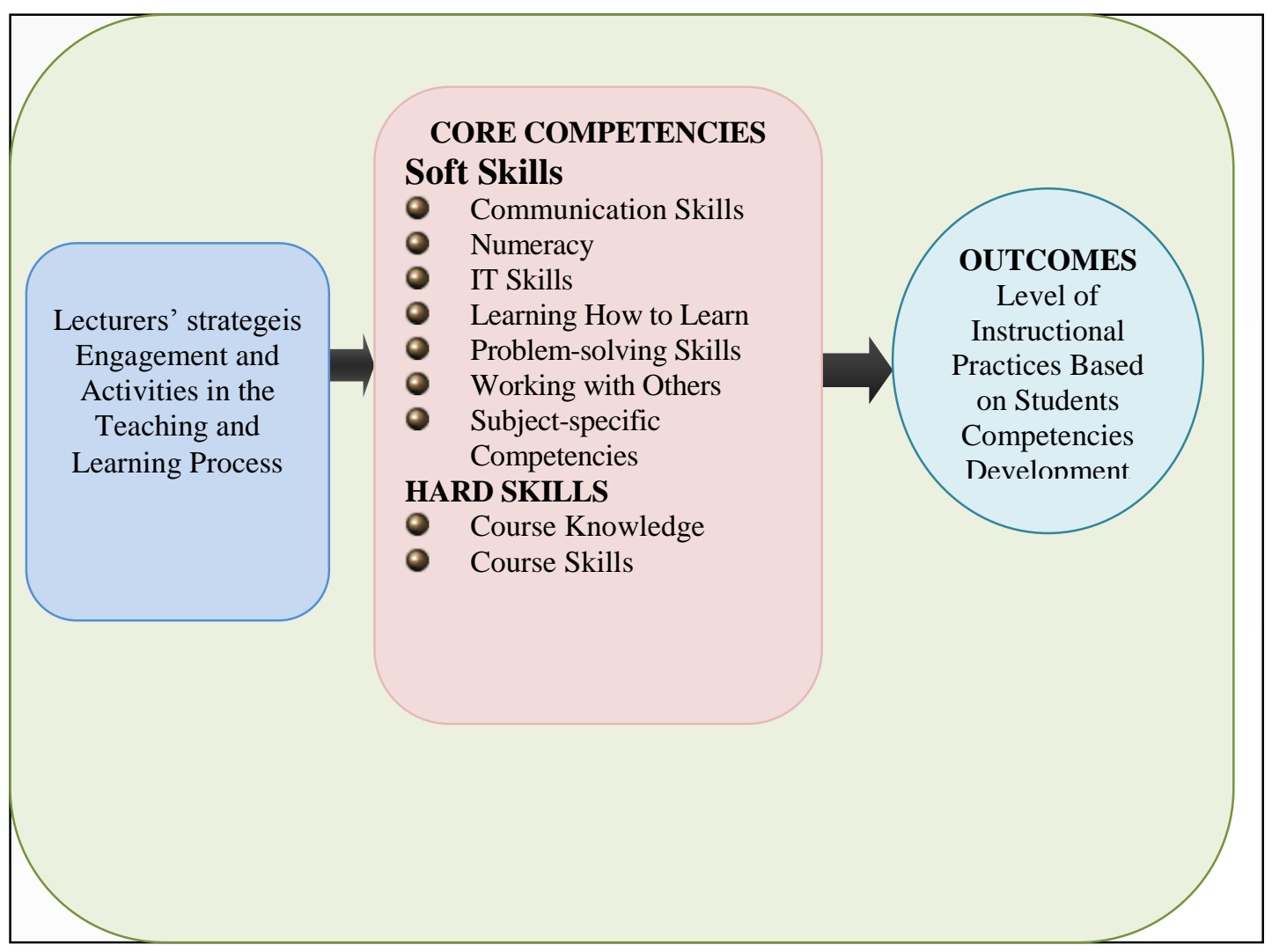

Figure 1. Conceptual framework of the study

The conceptual framework shown in Figure 1 illustrates how the students' engagement and activities were generated in the classroom in relation to the development of core competencies. The lecturers' strategies on students' engagement were indicated by indicators of core competencies as constructed in self-report questionnaire. The model of students' core competencies development discussed in this paper refer Hadiyanto, Mukminin, Failasofah. Arif, Fajaryani, and Habibi, 2017, Hadiyanto \& Suratno, 2015, Bialik, et., al. (2015), Hassan., et. al. (2013), Hadiyanto \& Mohammed Sani (2013), Hadiyanto.(2011), Hadiyanto, (2010), Person, Ann., et. al. (2009) and Zalizan., et al (2006).Then, core competencies define as skills developed 
during teaching and learning process at university in order to provide students with three major competencies; Soft Skills, English Hard Skills and Character.

\section{Soft Skill}

Hadiyanto (2010) stated that the term of soft skills is interchangeable terms with generic skills, key skills or transferable skills that the government and much of the industry to be essential for successfully work. Current popular term use to describe soft skills much similarly defined as 2tst century skills (ILO,2014., p.15; Partnership for $21^{\text {st }}$ century skills. 2008. p. 12). The definition of soft skills then in this research is defined as the ability of generating communication skills, IT Skills, numeracy skills, learning how to learn skills, problem-solving skills and working with others in completing task and work. Each soft skill is defined in the following.

Communication skill is defined as the ability of using English to express and exchange ideas by using feelings of thought a variety of verbal and non-verbal media, including speech and written text as also to synthesise information gained from relevant resources (Hadiyanto \& Sani, 2013; Hadiyanto, 2011; Hadiyanto, 2010; Zalizan et al, 2006; Washer, 2007).

IT Skills, that is the competence of using technology of computers as well as its' device and programme, such as using Microsoft office, internet, website, email, messenger, downloading and uploading, applications, online conference, necessary tool and application to access, gain, create, manage and expose information (Hadiyanto \& Sani, 2013; Hadiyanto, 2011; Hadiyanto, 2010; Zalizan et al, 2006; Washer, 2007).

Numeracy skill refers to the ability of using basic mathematic calculation, interpreting graphical information, timing, prioritizing tasks and sequencing of job or activities. (Hadiyanto \& Sani, 2013; Hadiyanto, 2011; Hadiyanto, 2010; Zalizan et al, 2006; Washer, 2007).

Learning skills is defined as the ability of using strategies as well as doing evaluation on self-learning strategy, seeking for the weakness and coming to better way and output of learning goal, it includes gaining general and detailed information, knowledge and skills in order to achieve the goal of learning (Hadiyanto \& Sani, 2013; Hadiyanto, 2011; Hadiyanto, 2010; Zalizan et al, 2006; Jones, 2009)..

Problem solving skills, which is the ability to tackle problem systematically and appropriately in appropriate situation in order come out with an appropriate solution (Hadiyanto \& Sani, 2013; Hadiyanto, 2011; Hadiyanto, 2010; Jelas et al., 2006; Washer, 2007).

Working with others refer to a capacity to interact effectively with other people both on a one to one basis and in groups, including understanding and responding to the needs of a client and working effectively as a member of a team to achieve a goal (Hadiyanto \& Sani, 2013; Hadiyanto, 2011; Hadiyanto, 2010, Jelas et al., 2006 ; Washer, 2007; QCA, 2000).

\section{Hard Skills}

Hard skills relate to specific knowledge and technical skills toward a field of study (Babic \& Slavkovic, 2011). Dikti (2011) stated hard skills that are refer to specific knowledge and technical skills toward one's major. Specifically in this study, it is 
defined the ability of students using and generating course knowledge and skills in real context.

\section{Instructional Practices Based On Students Competencies Development}

In relation to preparing the classroom for core competencies development certainly requires proper planning and preparation. Giving a full lecture or demonstrating the core competencies practices; soft skills and hard skills and are not proven methods of developing the skills among the students. The literature stresses the importance of both theory and practice as necessary elements in the process of learning (and the development of core competencies through real practice, yet many writers assert that students have difficulty in transferring theoretical concepts acquired in the classroom to practical applications in the workplace in areas as varied as aviation, all disciplines knowledge. For answering the issues some expert suggested that important opportunities for the development of core competencies must occur in the selection of delivery methods. Teaching contexts can provide an explicit focus on the development of core competencies, thus providing students with opportunities to develop them. The students 'core competencies will be highly promoted if the large opportunity given to the students to practice these attributes within learning activities and otherwise (Hadiyanto \& Suratno, 2015, Hassan., et. al. 2013, Hadiyanto, 2010).

Students learn most effectively when they have the opportunity to interact with other students. Interaction among students typically leads to group problem solving. When students are unable to meet together, appropriate interactive technology for learning such as E-mail, E-learning, Online learning, Online course some current ICT application, should be provided to encourage their it skills as well encourage their small group and individual communication. Assignments in which students work together and then report back or present to the class as a whole, encourage student-to-student interaction. Ensure clear directions and realistic goals for group assignments. Distant students need to reflect on what they are learning. They need to examine the existing knowledge frameworks in their heads and how these are being added to or changed by incoming information (Hadiyanto, 2010).

The concept and indicator of students' core competencies practice development in the instructional practice were retrieved form theories and concept of teaching and learning and then characterized into practical statements of core competencies. In daily teaching, hard skills are typically easy to observe, quantify and measure. The evaluation formally designs for this type of skills for every subject. However the hard skills in term practices in real contact were rarely measured by educator. Soft skills are typically hard to observe, quantify and measure by a test. Self- evaluation questionnaire model were developed to measure students' experience, learning activities, learning strategies and how they cope with E-learning, online learning and ICT based learning. 


\section{RESEARCH METHOD}

The sample of this study was all lecturers at English Education Department in Education and teacher training Faculty, Universitas Jambi (UNJA). The questionnaire was distributed to all English education lecturers (30) and only 23 of them were return. The data for this study were generated using a quantitative method. A questionnaire was conducted to elicit lectures' self-reports regarding their level of frequency in developing students core competencies in instructional practice.

The respondents were asked to respond statements of self-report questionnaire related to instructional practice based on students' core competencies development. The 5-point Likert scales (never, rarely, sometimes, often, and very often) were used. For example, to obtain the students' level of instructional practice of communication skills for statement A1 (asking the students to give a class presentation), they were asked to rate their level of practice by following scale never, rarely, sometimes, often, or very often. The mean score of the respondents' level of instructional practices were descriptively calculated and interpreted in five levels, as shown in Table 1.

TABLE 1. INTERPRETATIONS OF MEAN SCORES

\begin{tabular}{ll}
\hline Mean Score & Interpretation \\
\hline 1.00 to 1.80 & Very Low \\
1.81 to 2.60 & Low \\
2.61 to 3.40 & Medium \\
3.41 to 4.20 & High \\
4.21 to 5.00 & Very High \\
\hline
\end{tabular}

As shown in Table 1, a mean score between 1.00 and 1.80 indicates a very low level of core competencies, a mean score between 1.81 and 2.60 a low level, a mean score between 2.61 and 3.40 a medium level, a means score between 3.41 and 40 a high level of mean score.20, 4.21 and 5.00 a very high level of core competencies.

\section{RELIABILITY AND VALIDITY OF INSTRUMENTS}

Core competencies instrumentation in this study much referred to evaluation of selfquestionnaire developed by Zalizan, et.al (2006), QCA (2000), and adapted version by Hadiyanto 2011). However, the instrument was continuously updated based on current needs and KKNI based curriculum. The questionnaires were developed in two versions for students and for lecturer. The same constructs and indicators were developed for both version of questionnaire. Reliability and validity test were tested for students' version questionnaire resulted Cronbach alpha coefficient .60 and Corrected item-total correlation at 0.30 and above for all sub-construct consists were obtained, and coefficient .70 and above were obtained for three mains construct. These mean that consistency and validity of the instrument were obtained (Pallant, 2011; Hair, et al. 2009). Consistency testing also to lecturers' questionnaire version and resulted that $\alpha=$, 957 for overall Core Competencies, $\alpha=, 910$ for soft skills., and $\alpha=, 827$ for hard skills. In conclusion, the instruments are reliable and valid to be used for measuring the practices of Core Competencies for both students' learning and lecturers' instructional practices. 


\section{RESEARCH FINDINGS}

\section{Students' Core Competencies Development}

According to the findings, the lecturer yielded means score of instructional practices in overall (3.80 of 5.00) is at high level and the entire three mains construct also rated at high level of instructional activities, they were soft skills mean 3.70, hard skills 3.83 and core competencies at 3.80. A closer examination of the mean score given by the lecturer rated soft skills in terms of communication $(3,64)$; learning $(3,910$, problem solving (3.85) and team works skills (3.84) at high level of practices (see Table 1), while IT skills (3.35) and numeracy skills (3.29) were rated at medium level of practices. The findings imply that the instructional practices based on students' core competencies were applied. However, there were no soft skills at very high level of practices.

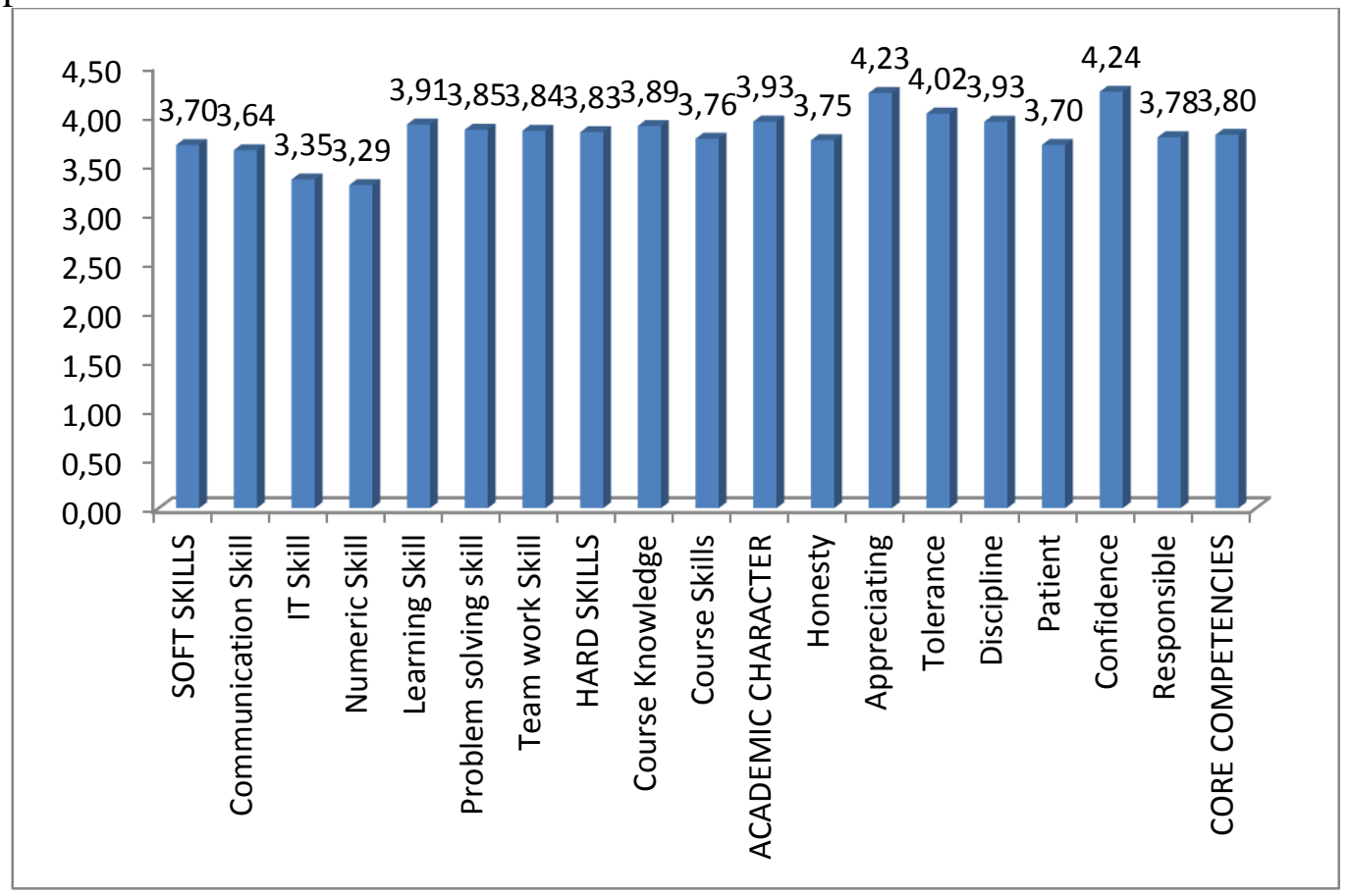

Graph 1. Overall Mean and Level of Instructional Practices based on Students' Core Competencies Development

\section{Students' Soft Skills Development}

As displayed in Table 2 the instructional practices of communication skill in overall was at high level (mean score 3.64). Thought varies mean scored yielded among indicator of communication skills. All indicators of communication skills were at high level (mean 3.41 to 4.20). Thought the means score of communication skills and its indicators were not at very high level, this finding signifies that student's communication skills were developed in the process of teaching and learning. 
TABLE 2. LEVEL OF STUDENT' COMMUNICATION SKILL DEVELOPMENT

\begin{tabular}{llcl}
\hline \multicolumn{1}{c}{ CORE COMPETENCIES } & Mean & S.D & Level \\
\hline A1. Doing presentation & 3,50 & 1,03 & High \\
A2. Using Different formats & 3,50 & 0,76 & High \\
A3. Using Vocabularies, Expressions and body language & 3,46 & 1,03 & High \\
A4. Integrating ideas or information & 3,62 & 0,94 & High \\
A5. Summarizing key issues (Oral) & 3,64 & 0,91 & High \\
A6. Giving feedback & 4,00 & 0,94 & High \\
A7. Communicating some ideas in writing & 3,81 & 0,69 & High \\
A8. Writing a report & 3,69 & 0,74 & High \\
A9. Summarizing key issues (written) & 3,58 & 0,76 & High \\
Communication Skills & 3,64 & 0,44 & High \\
IT Skills & Mean & S.D & Level \\
B1. Selecting relevant information from IT sources & 3,92 & 0,48 & High \\
B2. Sharing references and resources using IT and & 3,23 & 0,99 & Medium \\
applications & & & \\
B3. Developing assignment in the form of text, image, chart, & 3,08 & 0,98 & Medium \\
etc & & & \\
B4. Presenting using some illustrations in power point & 3,77 & 0,86 & High \\
B5. Using software or application features & 2,81 & 0,90 & Medium \\
B6. Developing the structure of presentation & 3,27 & 0,72 & Medium \\
Overall & 3,35 & 0,51 & Medium \\
\hline
\end{tabular}

\section{Students' It Skill Development}

The mean score of IT skills instructional practices as displayed in Table 3 was at the medium of 3.35. Furthermore, five of six indicators yielded means score at medium level (mean between $2.61-3.40$ ), they are indicator no B2, B3, B5 and B6. While indicators no B1 and B3 were rated at high level of mean score. The finding implies that students' IT skills was not frequently practice through instructional practice.

\section{Students’ Numeracy Skill Development}

Table 4 shows that overall mean score of lecturer instructional practice of numeracy skills was at medium level (mean score 3.29). Indicator no C1, C2, C5 and $\mathrm{C} 7$ yielded mean score at medium level (mean between $2.61-3.40$ ), while indicator number C3, C4, C6 and C8 were at high level. This finding signifies that the lecturer did not strongly encouraged students' numeracy skills in instructional practice.

TABLE 3. LEVEL OF STUDENTS' NUMERACY SKILL DEVELOPMENT

\begin{tabular}{llll}
\hline Numeracy Skills & Mean & S.D & Level \\
\hline C1. Reading tables, charts, graphs and numbers & 2,77 & 0,86 & Medium \\
C2. Measuring learning activities and outcome & 2,96 & 1,00 & Medium \\
C3. Using effective and efficient ways & 3,69 & 0,74 & High \\
C4. Presenting based on points but calculable & 3,46 & 0,81 & High \\
C5. Labeling tables, charts and graphs & 3,00 & 1,10 & Medium \\
C6. Managing time for working on assignment & 3,65 & 0,69 & High \\
C7. Improving on use of numeracy to support learning & 3,15 & 0,78 & Medium \\
C8. Identifying the relevant information sources & 3,62 & 0,80 & High \\
Overall & 3,29 & 0,61 & Medium \\
\hline
\end{tabular}




\section{Students' Learning How To Learn Skill Development}

Table 5 displays the instructional practices of learning how to learn skill in overall was at high level (mean score 3.91). Looking at indicators of LHTL shows that all indicators were rated at high level of instructional practice. Although, the level of LHTL and all indicators were rated at high level, yet there was no an indicator rated at very high level.

TABLE 4. LEVEL OF STUDENTS' LEARNING HOW TO LEARN SKILL DEVELOPMENT

\begin{tabular}{llll}
\hline Learning how to learn & Mean & S.D & Level \\
\hline D1. Improving academic performance & 4,38 & 0,64 & High \\
D2. Assessing the effectiveness and efficiency & 3,81 & 0,63 & High \\
D3. Identifying factors impacted on learning outcomes & 3,96 & 0,66 & High \\
D4. Setting realistic targets and plan & 3,46 & 0,81 & High \\
D5. Learning independently and be responsible & 3,88 & 0,59 & High \\
D6. Identifying ways my work best & 4,04 & 0,53 & High \\
D7. Putting together ideas or concepts & 3,69 & 0,79 & High \\
D8. Reviewing what and how to learn & 3,85 & 0,67 & High \\
D9. Consulting with lecturers & 4,19 & 0,57 & High \\
D10. Adapting learning strategy & 3,96 & 0,34 & High \\
D11. Comparing information from various resources. & 3,73 & 0,67 & High \\
Overall & 3,91 & 0,38 & High \\
\hline
\end{tabular}

\section{Students' Problem Solving Skill Development}

The findings in Table 6 show that problem solving skills in overall was instructional practiced of $\mathrm{CC}$ at the high (3.91). All indicators of instructional practice based on students' problems solving skills were also rated at high level except indictor no E6 was at medium level. In short, problem solving skills were encouraged by the lecturers in the classroom, but it was not at very high level.

\section{TABLE 5. LEVEL OF STUDENTS' PROBLEM SOLVING SKILL DEVELOPMENT}

\begin{tabular}{llll}
\hline Problem Solving & Mean & S.D & Level \\
\hline E1. Identifying a problem & 4,23 & 0,51 & High \\
E2. Solving problems with several ways & 4,12 & 0,33 & High \\
E3. Using different methods to analyses a problem & 3,77 & 0,43 & High \\
E4. Accommodating diverse perspectives & 3,88 & 0,65 & High \\
E5. Solving problems by resources provided & 3,69 & 0,55 & High \\
E6. Presenting an approach to solve a problem & 3,31 & 0,74 & Medium \\
Overall & 3,96 & 0,53 & High \\
\hline
\end{tabular}

\section{Students' Working With Others Skill Development}

As displayed in Table 7, the lecturer rated the instructional practice based on working with other skill was at high level (mean score 3.84). All indicators were also rated at high level, however there was no indicator rated at mean score 4.20 and above. This implied that the instructional practice did not optimally developed students' working with other skills. 
TABLE 6. LEVEL OF WORKING WITH OTHERS DEVELOPMENT

\begin{tabular}{lccc}
\hline Working with Others & Mean & S.D & Level \\
\hline F1. Learning activities in a group & 4,31 & 0,47 & High \\
F2. Having conversations with different races in learning & 3,65 & 0,69 & High \\
F3. Working in team & 4,00 & 0,75 & High \\
F4. Resolving conflicts in team work & 3,69 & 0,74 & High \\
F5. Giving feedback to improve team work & 3,46 & 0,71 & High \\
F6. Keeping yourself and others motivated & 3,96 & 0,34 & High \\
F7. Respecting diverse perspectives & 3,81 & 0,80 & High \\
F8. Thinking and offering ideas to a group work & 3,85 & 0,67 & High \\
Overall & 3,84 & 0,40 & High \\
\hline
\end{tabular}

\section{Students' Hard Skills Skill Development}

Hard skills findings for both course knowledge and course skills were rated high level of mean score. All indicators of course knowledge and skills were also at high level. It was supposed to give very high mean score, due to these competencies relate to their course content. The findings implied that the students were more provided theoretical basis rather than competencies itself. They were not very highly prepared enough to acquire how to apply knowledge into real practice or real world. The findings are displayed in Table 6.

TABLE 7. LEVEL OF STUDENTS' HARD SKILLS DEVELOPMENT

\begin{tabular}{llll}
\hline Hard Skills & & & \\
\hline Course Knowledge & Mean & S.D & Level \\
G1. Presenting course content specifically both oral and & 3,77 & 0,71 & High \\
$\quad$ writing & & & \\
G2. Discussing specific course content with your colleaque & 3,78 & 0,70 & High \\
G3. Connecting course content across topics & 3,96 & 0,53 & High \\
G4. Answering questions, giving specific and practical & 3,96 & 0,72 & High \\
$\quad \quad$ explanations & & & \\
G5. $\quad$ ontributing specific ideas of course content in group & 4,00 & 0,63 & High \\
$\quad \quad$ work & 3.89 & 0,49 & High \\
Overall & Mean & S.D & Level \\
Course Skills & 3,81 & 0,49 & High \\
G6. Practicing the course content knowledge & 3,85 & 0,67 & High \\
G7. Applying what has been studied & 4,04 & 0,45 & High \\
G8. Applying course skills in practical assignment & 3,58 & 0,70 & High \\
G9. Giving an example of the course content practices & 3,54 & 0,65 & High \\
G10. Improving and updating course skills & 3,76 & 0,43 & High \\
Overall & & & \\
\hline
\end{tabular}

\section{DISCUSSION}

In general, the findings indicated that the respondents were able to distinguish clearly between the three main constructs of the core competencies; soft skills and hard skills as well as of its' sub-construct. The lecturers were able to reflect on their own level of instructional practices of students' core competencies development, and to identify which of the core competencies they practised in each level. 
The finding indicates that there is an effort of lecturer to develop students' core competencies through instructional practice. However, most of skills were represented at bottom of mean score of high level. This means that the students' core competencies development was still needs much improvement until obtain optimal level of mean score, for instance 4.21 and above, while students' core competencies development in two main constructs and most of sub-constructs obtained mean of bottom high level only. Moreover, lecturers demonstrated instructional practices are at a medium level of soft skills in term of IT and numeracy skills. In short, lecturers were not optimally facilitating the students to practice the skills.

Though the findings indicate that the lecturer enhances students' core competencies in teaching process but that the English students were not strongly prepared to acquire it. The graduates must be able to comprehend and analyse current and future work challenges with a critical mind and use their core competencies to develop their self-quality, succeed in their career, satisfy stake-holder, and none less contribute to their country. It is particularly important, due to the lack of core competencies practice among the students, that Faculty should encourage lecturers to implement learning activities that aim to improve students' core competencies to ensure a minimum mean score of 4.21 and above, that is, the 'very high level' banding of core competencies. Specifically for hard skills, the finding implied that the students were more provided theoretical basis rather than competencies its self. They were not very highly prepared enough to acquire how to apply and experience the knowledge into real practice or real world.

Though the findings of lecturers surveys revealed that core competencies was developed in instructional practices at high level, however the finding could not be used as a whole picture of core competencies development in teaching and learning process. Some limitations of this findings might be addressed, the result only based on lectures perception, and it could be generalized only for lecturer based selfevaluation only, and subjectivity might violate a real picture of weak core competencies instructional practices. Because the data were not supported yet by observation and syllabus analysis, about how the lecturers embedded core competencies in learning and teaching process. That is why, further investigation of this research going to see form students perspective, observation, interview and syllabus analysis.

\section{CONCLUSION}

This study was conducted at Department of English Education, Faculty of Education and Teacher Training, Universitas Jambi in order to identify the level of core competencies development being applied through the instructional practices activities. This research concludes that lecturers perceived developed the students' core competencies, in the two main constructs, soft skills and hard skills were at high level. Lecturers rated four components of soft skills, they were communication skills, learning how to learn, problem solving skills, and working with other were highly applied in students learning process. However there was no component of soft skills and it's indicators rated at high level. Two components of soft skills, IT and numeracy skills were rated at medium level of mean score, these mean that both soft skills were not frequently practice through instructional practice. In term of hard skills findings, lecturers rated both course knowledge and course skills were at high level. All 
indicators of course knowledge and skills were also at high level. The findings implied that the students were more provided with theory and concept of course content rather than practical and technical skills of course competencies. A grand conclusion revealed that core competencies highly practiced in instruction; however it did not obtained optimal level of core competencies practice in lecturers' instruction.

The result could not be used to portrait whole core competencies practices at the English education department. Students' perception on the practices of core competencies was not yet revealed. Further study using students' questionnaire, observation and in depth interview must be conducted to picture out comprehensive findings of core competencies practices in teaching and learning process. Finally, this study contributes to the issues surrounding the development of core competencies from a perspective of a university in Indonesia, and its results can be used to inform, support and data for further research in the issues of core competencies development.

\section{REFERENCES}

[1] Babić, V. and Slavković, M. 2011. Soft and Hard Skills Development: A Current Situation in Serbian Companies. University of Kragujevac, Serbia University of Kragujevac, Serbia.

[2] Bartel, J. 2011. "Soft Skills: What, Why and How to Teach Them in ESL Classes Using Office Soft Skills," presented at the TESL Toronto Spring Conference, May 2011. http://tesltoronto.org/wp-content/uploads/2011/05/BartelSoftSkillsSpring2011-.pdf.

[3] Bialik, M. Bogan, M. Fadel, C. and Horvathova, M. 2015. "Character Education for the 21st Century: What Should Students Learn?,” Survey of Outcomes Measurement in Research on Character Education Programs.

[4] Bath, D. Smith, C. Stein, S. and Swann, R. 2004. "Beyond Mapping and Embedding Graduate Attributes: Bringing together Quality Assurance and Action Learning to Create A Validated and Living Curriculum," Higher Education Research and Development., 23(3):313-28.

[5] Bennett, N. Dunne, E. and Carre, C. 2000. Skills Development in Higher Education and Employment. Buckingham: SRHE \& Open University Press.

[6] British Council. 2016. "English and Soft Skill in The Magreb," British Council and Casrfax Educational Projects. https://www.britishcouncil.org/sites/default/files/english-soft-skillsmaghreb-research-report.pdf

[7] Business Council of Australia (BCA). 2006. New Concepts in Innovation: The Keys to a Growing Australia. Melbourne: BCA.

[8] Borthwick, J. and Wissler, R. 2003. Postgraduate Research Students and Generic Capabilities: Online Directions. Canberra: Department of Education, Science and Training Research Evaluation Programme.

[9] Crebert, G. Bates, M. Patrict, C. and Cragnolini, V. 2004. "Developing Generic Skills at University, During Work Placement and In Employment: Graduate's Perceptions", HERD., 23(2):148-64.

[10] Curry, P. Sherry, R. and Tunney, O. 2003. What Transferable Skills Should Students Develop During Their Time in College: Results of Modern Languages Students Survey. Trinity College, Dublin.

[11] Direktorat Jendral Pendidikan Tinggi. 2011. Kerangka Kualifikasi Nasional Indonesia. Kajian Tentang Implikasi Startegi Implimentasi KKNI. http://penyelarasan.kemdiknas.go.id/uploads/file/Buku\%20Qualification\%20Framework\%20DI KTI.pdf

[12] English Education Program, Faculty of Teacher Training and Education, Universitas Jambi. 2015. KKNI Curriculum. https://english.unja.ac.id/index.php/academics/curriculum/64curriculum-kkni

[13] Hadiyanto, Mukminin, A. Failasofah. Arif, N. Fajaryani, N. and Habibi, A. 2017. "In Search of Quality Student Teachers in a Digital Era: Reframing the Practices of Soft Skills in Teacher 
Education," TOJET: The Turkish Online Journal of Educational Technology., 16 (3). http://www.tojet.net/volumes/v16i3.pdf

[14] Hadiyanto, and Sani, M. 2013. "Students' generic skills at the National University of Malaysia and the National University of Indonesia," Procedia - Social and Behavioral Sciences., 83 (2013): 71-82. www.sciencedirect.com

[15] Hadiyanto, and Suratno.2015. "The Practices of Students' Generic Skills among Economics Students at National University of Indonesia," Higher Education Studies., 5(2).

[16] Hadiyanto. 2010. "The Development of Core Competencies at Higher Education: A Suggestion Model for Universities in Indonesia," Educare., 3(1).

[17] Hadiyanto. 2011. The Development of Core Competencies Among Ecomics Students in National University of Malaysia (UKM) and Indonesia (UI). Ph.D Thesis. Faculty of Education, National University of Malaysia.

[18] Hair, J.F. Black, W.C. Babin, B.J. and Anderson, R.E. 2009. Multivariate Data Analysis. 7th Edition, Pearson, New York.

[19] Hashima,N. A. A. and Valdez, N. P. 2016. "Debate as A Pedagogical Tool to Develop Soft Skills in EFL/ESL Classroom: A Qualitative Case Study," Social Sciences and Humanity., 24 (1): 213-240. https://www.researchgate.net/publication/298710716_Debate as_a_pedagogical tool to develo p_soft_skills_in_EFLESL_classroom_A qualitative_case_study

[20] Hassan. A. Maharoff. M. and Abiddin. Z.N. 2013. "The Readiness Of Lecturers In Embedding Soft Skills In The Bachelor's Degree Program In Malaysian Institutes of Teacher Education," Journal of Education and Training Studies., 2(3): Red fame Publishing, Retrived from: http://jets.redfame.com

[21] Hogarth, T. Winterbothman, M. Hasluck, C. Carter, K. Daniel, W. W. Green, A. E. and Morrison, J. 2007. "Employer and University Engagement in the Use and Development of Graduate Level Skills," Research Report of Institute for Employment Research University of Warwick, United Kingdom. Retrieved from www.education.gov.uk/publications

[22] ILO. 2014. "Survey of ASEAN Employers on Skills and Competitiveness. Emerging Markets Consulting," Retrieved from http://www.ilo.org/wcmsp5/groups/public/---asia/---ro-bangkok/--sro-bangkok/documents/publication/wcms 249982.pdf

[23] Irma, D. 2007. "Soft Skill? Pikiran Rakyat,” Thursday, June 17.

[24] Jones, A. 2009. "Redisciplining Generic Attributes: The Disciplinary Context in Focus," J Stud High Educ., 34(1):85-100.

[25] Laura, H. Lippman, Renee, R. Carney, R. and Kristin A. 2016. Moore Child Trend. Workforce Connections: Key "Soft Skills" That Foster Youth Workforce Success: Toward a Consensus Across Fields. https://www.usaid.gov/sites/default/files/documents/1865/KeySoftSkills.pdf

[26] Magy, R. and Price, D. 2012. "Soft Skills that Learners Need for Academic and Workplace Settings," Presented at Catesol, April 2012. https://www.quia.com/files/quia/users/donnapm/CATESOL_2012 handout_040412 revFINAL. $\underline{\mathrm{pdf}}$

[27] Lowden, H. and Hall, S. 2011. Employers' Perceptions of the Employability Skills of New Graduates. London, Edge Foundation. Retrieved from www.edge.uk

[28] Norzaini, A. Manisah. Ali, M. Tamuri, A.H. and Zalizan, M. Jelas. 2005. "Effective Higher Educational Practices: A Survey of Student Engagement," Malaysian Journal of Learning and Instruction., 2: 95-119.

[29] Zalizan. Jelas, M. and Azman, M. 2005. "Generic Skills Provision In Higher Education: A Malaysian Perspective,” The International Journal of Learning., 12(5):200-10.

[30] Zalizan, Jelas, M. Azman, N. Ali, M. M. Nordin, N.M. and Tamuri, A.H. 2006. "Developing Generic Skills at Graduates: A Study of Effective Higher Education Practices in Malaysian Universities," Summary Report. Kuala Lumpur, Universiti Kebangsaan Malaysia, Faculty of Education.

[31] Pallant, J. 2011. A Step by Step Guide to Data Analysis Using SPSS Program. Survival Manual. $4^{\text {th }}$ Edition. China, Everbest Printing.

[32] Partnership for 21st Century Skills. 2008. "21st Century Skills, Education \& Competitiveness," A Resources and Policy Guide. Retrieved 21, February, 2017, from http://www.p21.org/storage/documents/21st_century_skills_education_and_competitiveness_gui de.pdf 
[33] Pumphrey, J. \& Slater, J. 2002. “An Assessment of Generic Skills Needs,” Skills Dialogues Report No. 13, Nottingham: Dfes.

[34] Qualifications and Curriculum Authority. 2000. Key Skills Units (Levels 1-5). London, QCA.

[35] Scottish Qualifications Authority. 2003 "Key Competencies: Some International Comparisons: Policy and Research," Research Bulletin, http://www.sqa.org.uk/files_ccc/Key_Competencies.pdf. August 29, 2009.

[36] Su, and Zang. 2015. "An Integrative Model For Measuring Graduates’ Employability Skills-A Study In China," Published Article in Kingston University, London. Retrieved from http://zwww.tandfonline.com/doi/full/10.1080/23311975.2015.1060729

[37] Tim Kurikulum dan Pembelajaran Direktorat Pembelajaran dan Kemahasiswaan. 2014. Kurikulum Pendidikan Tinggi.Direktorat Pembelajaran Dan Kemahasiswaan Direktorat Jenderal Pendidikan Tinggi Kementerian Pendidikan dan Kebudayaan. http://lpm.walisongo.ac.id/wp-content/uploads/2016/06/Panduan Kurikulum-Dikti.pdf. Retrieved on May 282016

[38] Washer, P. 2007. "Revisiting Key Skills: A Practical Framework for Higher Education,” Journal of Quality in Higher Education., 13(1): 57-67. 